\title{
THE RELEVANCE OF HUMAN RIGHTS COUNCIL SPECIAL SESSIONS: THE PROTECTION OF THE CIVILIAN POPULATION IN CURRENT INTERNAL ARMED CONFLICTS
}

\begin{abstract}
Sónia Roque
sroque@live.com.pt

PhD student in International Relations at the Faculty of Economics, University of Coimbra-Center for Social Studies (FEUC-CES, Portugal). Scholarship Holder of the Foundation for Science and

Technology.
\end{abstract}

\begin{abstract}
This article focuses on the analysis of the first decade (2006-2016) of the Human Rights Council (HRC) work. We analyze particularly the relevance of the HRC special sessions in what concerns to the protection of civilians in current non-international armed conflicts (NIAC). The HRC, that replaced the Commission on Human Rights, was established by the United Nations General Assembly (UNGA) Resolution 60/251 adopted on 15 March 2006. This institutional reshaping intended to transform the HRC into an action-oriented body, in an attempt to give a more effective and rapid response to global human rights (HR) protection challenges.

Following the 2004 Report of the High-Level Panel on Threats, Challenges and Change, the United Nations General-Secretary Kofi Annan drew attention to the fact that a decisive moment for the United Nations (UN) had began. Kofi Annan highlighted in particular the need to fulfill the aspirations established in the United Nations Charter (UNC), and emphasized in general terms the challenges facing HR protection, particularizing the protection of the civilian population given the complexity of our days armed conflicts. Therefore the HRC appears in this line of institutional restructuring.

The special sessions are one of the working methods of the HRC which allows the consideration of gross HR violations that need attention and require an urgent decision-making. The author argues that the analysis of these sessions is particularly relevant, because it allows us, on the one hand to examine which situations were analyzed, and on the other hand the different positions regarding this decision-making method that has not always proved consensual. I also argue that this decision-making procedure reflects some opportunities and faces challenges in trying to deal with the different perspectives of the actors within the HRC.
\end{abstract}

\section{Keywords}

Human Rights Council; Special Sessions; Protection; Civilian Population; Internal Armed Conflicts

How to cite this article

Roque, Sónia (2019). "The relevance of Human Rights Council special sessions: the protection of the civilian population in current internal armed conflicts". JANUS.NET e-journal of International Relations, Vol. 10, N. ${ }^{1}$, May-October 2019. Consulted [online] on the date of the last visit, https://doi.org/10.26619/1647-7251.10.1.3

Article received on May 24, 2018 and accepted for publication on September 4, 2018

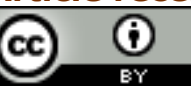




\section{Introduction}

The HRC was established by the UNGA Resolution A/RES/60/251 adopted on 15 March 2006 replacing the Commission on Human Rights. The Commission had been criticized for being a highly politicized body (Sheeran and Rodley, 2013: 745), in which countries were seeking seats to avoid the discussion of their HR internal situation, and the approval of measures such as the appointment of fact-finding missions, commissions of inquiry or even the adoption of sanctions, by which the mission that gave rise to it "the protection of the victims of HR abuses" became a protective shield for the offenders (Lauren, 2007: 307).

It is therefore not surprising that when talking about the need for more comprehensive reforms in the UN system, special attention was devoted to replacing the Commission on Human Rights and to the importance of HR for collective security (Lauren, 2007: 330331), as discussed after the World Summit, in the report of the High-Level Panel on Threats, Challenges and Change entitled "A more secure world: our shared responsibility", as well as in the report of the United Nations Secretary-General (UNSG) Kofi Annan "In larger freedom: towards development, security and human rights for all".

On this issue Cox (2010: 95) emphasized the fact that the UNSG, the UN High-Level Panel, and a growing number of Member States have lobbied in such a way that the Commission began to be seen by many as a problematic institution that needed to be replaced. As the World Summit in 2005 demonstrated, the idea of replacing the Commission on Human Rights took over the UN, leading to a constant pressure to replace this body that States may have perceived as a reputation cost if they did not support a new institution. The HRC was therefore established in this sense as an action-oriented body as set out in Resolution 60/251. Its status was also elevated to a subsidiary body of the UNGA, which gave to this body greater powers of action and a higher autonomy as advocated by the UNSG.

1 The translation of this article was funded by national funds through FCT - Fundação para a Ciência e a Tecnologia - as part of OBSERVARE project with the reference UID/CPO/04155/2019, with the aim of publishing Janus.net. Text translated by Cláudia Tavares. 
From a constructivist point of view, the negotiation process and the establishment of the HRC itself denote the influence that agents can have on the structure of the United Nations (Ruggie, 1998; Wendt, 1995). Since we are dealing with an intergovernmental process the role of the UNSG, the role of the Experts appointed by the SGNU and the position of the Member States responsible for the decision-making were central in the whole process.

Among the working methods of the HRC is the holding of special sessions which take place whenever $1 / 3$ of the Member States consider that there is a flagrant situation of HR abuses that require attention and an urgent decision-making (A/RES/60/251: 4). This method was sought as a way to counteract the political blockade that had begun to discredit the work of the Commission, which allows us to infer about the importance of these sessions for the protection of HR.

The convening of these sessions was also made more flexible compared to what happened in the Commission. Besides analyzing the situation in specific countries, it is also possible to hold sessions on topics on the field of HR (thematic sessions). Another innovation was the reduction of the number of States needed to convene these sessions, which allows urgent issues to be discussed in the HRC more easily (ICRC, 2008: 490). All these innovations were aimed to respond quickly to HR urgent needs.

\section{Special Sessions}

Between 2006 and 2016, the first decade of the HRC work, which can be considered as a milestone for the analysis of its performance, in which all expectations were put into the work of this new body, were held $26^{2}$ special sessions. This reveals on the one hand, the greater capacity of performance and analysis of the HRC and, on the other hand, the greater facility of convening these sessions. These sessions will be analyzed from the point of view of their contribution to the protection of civilians in NIAC, taking into account the initiative of their convocation, the contributions and positions for the decision-making and the final result of the session in order to infer about the fulfillment of these expectations.

\section{Sudan}

The first case in the ambit of our analysis to be taken before the HRC was the HR situation in Sudan. This was the HRC fourth special session convened by Finland (A/HRC/S-4/1). The session was supported by States from the various continents including Cuba, Russia, China, India and Ecuador, which show greater susceptibility to interference in States internal affairs. This could lead to a good prognosis for the HRC work. Nevertheless this session had the opposition from the State concerned, Sudan that however participated in the session, as did all States whose internal situation was analyzed. The States position indicates, on the one hand, the acceptance of the competence of international bodies in which States decide to participate, in this case, the HRC, and on the other hand, their attempt to influence the decision-making of these bodies.

27 of these sessions referred to the Israel-Palestine conflict characterized by the UN as an international conflict (TIJ, 2004: 7-8). The 7th, 10th and 13th sessions do not refer to armed conflict situations. 


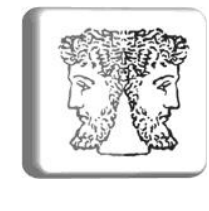

The information presented by the Independent Experts, the HRC Special Rapporteurs and by the UN Special Representatives is essential in these sessions and in general terms to the HRC decision-making. They are responsible for presenting concrete information on each situation whose credibility or veracity is difficult to challenge, since the functions of these experts are part of a mandate given to them in the framework of the UN system and, as such, accepted by the UN Member States. This is a fundamental component of the HRC work. As an intergovernmental political body the independence of these Experts from Member States is crucial in the analysis of HR situations. Although cooperation is the essential engine of this interaction, the work and independence of these Experts allows them to persuade States to change their positions and perceptions regarding the various issues as analyzed by Constructivism, and in our case, in what concerns to the protection of the civilian population ${ }^{3}$.

The seriousness of the HR situation in Sudan, in particular, the offenses and abuses against civilians, had come to the attention of the Commission, but without great practical results. At the meeting, the representative of the Commission of Inquiry on Darfur, the UNSG Special Adviser on the Prevention of Genocide, the UNSG and the United Nations High Commissioner for Human Rights (UNHCHR) emphasized the attacks on civilians who were sometimes instigated by the government itself. The UNHCHR specifically enumerated these HR and International Humanitarian Law (IHL) violations (torture and other cruel, inhuman or degrading treatments; sexual violence and other abuses; the displacement of civilians; the looting of civilian property; the obstruction of humanitarian assistance; the threats of murder; the impediment to the return of internally displaced persons (IDPs); arbitrary arrests and detentions).

In line with these reports, Finland, the promoter of the session, introduced the draft resolution A/HRC/S-4/L. 1 in which concern was expressed regarding the humanitarian and $H R$ situation in Darfur and a call was made on the end of HR and IHL violations (A/HRC/S-4/L.1: 1-2). Alternatively, Algeria, on behalf of the African Group (AG), presented the draft resolutions A/HRC/S-4/L.2 and A/HRC/S-4/L.3. These proposals did not contain any recognition of HR and IHL violations despite the information given by the Independent Experts and Finland's proposal. In this session as a result of the divergent positions of Member States was approved the Decision S-4/101 adopted without a vote. In this Decision, in general terms, the HRC Member States expressed their concern about the humanitarian and HR situation in Darfur and decided to send a High-Level Mission to assess the HR situation and the needs of the country in this regard (A/HRC/S-4/5: 3).

The AG's position indicates the lack of support for a strong and condemnatory action on the situation in Darfur, which reveals at this early stage of the HRC's work a reluctance of most States in adopting measures which could have internal implications particularly at the criminal responsibility level. However the seriousness of the situation proven by the information presented led to the appointment of a fact-finding mission, demonstrating the importance of the Experts reports on the situation and the pressure on the need to continue to monitor the humanitarian and HR situation in Sudan. The focus on the protection of civilians in Sudan and the pressure to achieve an improvement

3 By civilians, as provided for in Article 50 of the I Additional Protocol to the Geneva Conventions (GC), we mean persons who are not members of the armed forces; the civilian population comprises all persons who are civilians. Some practice adds the condition that civilians are persons who do not participate in hostilities (ICRC, 2005). 
of the situation on the ground led to the analysis of the situation in regular sessions, in which support from the govern and the AG was obtained.

\section{South Sudan}

Albania, Paraguay, the United Kingdom and the United States of America (USA) requested a session about the HR situation in South Sudan, the HRC 26th special session (A/HRC/S-26/1). This session had an interregional support, except from Venezuela and South Sudan. Nevertheless South Sudan was willing to cooperate, reserving however its sovereign right to take appropriate measures in a timely manner. This position reveals that sovereignty remains an unavoidable point in international relations, although we may regard cooperation as a counterweight to this situation in the sense analyzed by Wendt (1995). According to this author the interaction in social structures (in which we can include the HRC) can shape the identities and interests of the actors that seek also legitimacy and international recognition.

We should begin by highlighting the independence of South Sudan from the State of Sudan in 2011 and that despite the HR and IHL violations reported since 2006, as we discussed on the special session on Sudan, no special session on the situation was requested, being the regular forums considered sufficient to monitor the situation.

In the session the UNHCHR referred to HR violations in the country such as abductions, arbitrary arrests and forced displacement and violations of civil and political rights (freedom of movement, expression and opinion). The HR Commission in South Sudan has denounced these offenses, including infractions against children, highlighting the process of ethnic cleansing in the country also mentioned by the UNSG Special Adviser on the Prevention of Genocide. The imminence of hunger; the reduction of civil society groups and the increasing number of refugees and IDPs were also mentioned. For its part, the Chair of the Coordination Committee of HRC Special Procedures (CCSP) referred in particular to the sexual and gender-based violence used as a tool for ethnic cleansing and also to the attacks on civilian infrastructures and sites; forced recruitment of children; enforced disappearances; torture and ill-treatment and extrajudicial executions.

Taking the initiative of the decision-making the USA introduced the draft resolution A/HRC/S-26/L. 1 which was adopted without a vote in Resolution S-26/1 (A/HRC/S-26/2: 9). This shows the support of the AG in this late stage of HRC work regarding the need of ensuring the protection of civilians. This Resolution included references to the infractions against civilians as mentioned by the Experts. It also included the issue of the accountability of offenders and the government's responsibility to protect its population from genocide, war crimes, ethnic cleansing and crimes against humanity (A/HRC/S26/L.1: 2-4). The project also noted the importance of providing timely assistance and protection to survivors of sexual and gender-based violence, taking into account the needs of people with disabilities and referred to the restrictions on HR and fundamental freedoms (A/HRC/S-26/L.1: 3). These references clearly link IHL to the safeguards of International Human Rights Law (IHRL) in protecting civilians, a significant step in the protection of civilians compared to the restrictive Decision approved in the fourth special session. 


\section{Myanmar}

The HR situation in Myanmar was examined at the initiative of Slovenia on the HRC fifth special session (A/HRC/S-5/1). However this session was not supported by Myanmar, Russia and India. This situation demonstrates that States don't like to be targeted directly in a specific session that blames them for failures in HR protection, but which can be achieved under the new HRC working rules, which highlights the significance of the structures in which States participate.

Regarding Myanmar, the Special Rapporteur on Myanmar warned about the violent repression of peaceful demonstrations by security forces and the restrictions on the media. Among the blatant violations were summary executions; restrictions on the freedom of religion and expression; torture and ill-treatment; lack of independence of judges and lawyers, as well as arbitrary arrests and detentions. The infractions were reinforced by the information provided by the UNHCHR.

These reports were included in the draft resolution A/HRC/S-5/L. 1 submitted by Portugal on behalf of the European Union (EU) adopted without vote in the Resolution $S-5 / 1$ (A/HRC/S-5/2: 8). It was consensual to include besides the protection of the life and the physical integrity of civilians, the need to respect HR and fundamental freedoms such as peaceful political activities, guaranteeing also the freedom of peaceful assembly and association and the freedom of opinion and expression, including for free and independent media, and to ensure unhindered access to media information in Myanmar (A/HRC/S-5/L.1: 1-2). In spite of the initial reluctance cooperation was obtained for the resolution's approval as well as the consensus of Myanmar, Russia and India, evidencing the costs of reputation of States, due to the reports of the Experts and the mandate given to the HRC in which they agree to participate.

\section{Democratic Republic of the Congo (DRC)}

France had the initiative on the analysis of the HR situation in the DRC (A/HRC/S-8/1). This was the HRC 8th special session.

In what concerns to HR violations the UNHCHR has reported in the country the occurrence of summary or arbitrary executions; widespread abductions; looting and sexual violence and abuses, including against IDPs, women and children. In this regard, as the facilitator of the session, France presented, on behalf of the EU, the draft resolution A/HRC/S-8/L.1, but after long discussions on the proposal A/HRC/S-8/L.2/Rev.2 submitted by Egypt on behalf of the $A G$ and the consensus reached, withdrew the draft. This allowed Resolution S-8/1 to be adopted without a vote in order to secure a consensus regarding the protection of civilians.

The initial proposal presented by Egypt A/HRC/S-8/L.2 was drafted in general terms, without reference to acts of infraction. The pressure made by the promoters of the draft resolution L. 1 achieved consensus on the inclusion of the reference to offenses committed in Kivu against civilians, in particular sexual violence, child militia recruitment and the need for accountability for HR and IHL violations (A/HRC/S-8/L.2/Rev.1: 2). This achievement proves the relevance of the actors identities in the HRC structure and the mutual influence of these actors in the HRC work. The importance given to humanitarian assistance (food, water, medicines and shelter) and to the free movement of people and 


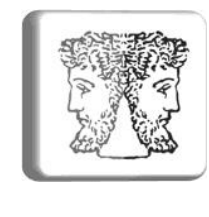

goods were also mentioned, going beyond the protection of the physical integrity and dignity of civilians, increasingly consensual among States.

\section{Sri Lanka}

The HR situation in Sri Lanka was assessed at the HRC 11th special session on the initiative of Germany (A/HRC/S-11/I). This session was supported mostly by the Western European and Other States Group, with resistance from the countries of other continents and from Sri Lanka. This opposition was based on the argument that this was an internal situation of fight against terrorism.

The UNHCHR seeking to achieve progress in the protection of civilians has reported the existence of $H R$ and IHL violations in the country (killings; forced displacement; destruction of property and livelihoods; lack of food, water and medical assistance and lack of independence of national institutions). It also referred to the importance of assisting the victims of violence that should have access to justice and remedies.

However, given the opposition to the session and in order to influence the final decision, Sri Lanka presented the draft resolution A/HRC/S-11/L.1. In this proposal only the offenses of the Tamil Tigers Eelam were mentioned. In the first amendment to the draft resolution that resulted in Resolution S-11/1 (A/HRC/S-11/2: 10), there was an attempt to reach consensus, given the refusal to accept Germany's proposal and some progress was made. To the protection of civilians was added the responsibility of the State to provide protection and humanitarian assistance (water, sanitation, food, medical care) and the obligation to respect IHRL and IHL. There was evidence that the protection of civilians was still insufficiently guaranteed by this proposal, and therefore this Resolution did not count with the support of the States that promoted the session. A main argument to this opposition was the fact that the infractions committed by the government were not included in the Resolution.

\section{Ivory Coast}

The 14th special session about the HR situation in Ivory Coast was requested by Nigeria (on behalf of the AG) and the USA (A/HRC/S-14/1: 4-5). The AG's position had been of cooperation within the HRC. This Group tried to solve or manage the HR problems on the Continent also through a decision-making position.

The Deputy High Commissioner for Human Rights reiterated, on behalf of the UNHCHR, the concern about HR violations in the country (repression of public meetings and demonstrations; harassment and intimidation; arrest and arbitrary detentions; torture; enforced disappearances; extrajudicial killings; forced displacements; violations of the freedoms of information, expression and the freedom of movement) which hindered the provision of humanitarian services and assistance.

Following the initiative to convene the meeting Nigeria, on behalf of the AG, introduced the draft resolution A/HRC/S-14/L.1. This proposal was adopted consensually in Resolution S-14/1 (A/HRC/S-14/1: 6-7). On the Ivory Coast HR situation, HR and IHL violations committed by all parties to the conflict were considered as reported by the Special Representative, including against fundamental rights and freedoms such as the freedom of information and expression. The impact of the conflict on the provision of 
humanitarian assistance, including the socio-economic impact on the population was another important issue. The protection level granted by the Resolution goes beyond the protection that would be conferred under IHL according to common Article 3 to the GC (the only one accepted by all States in NIAC), specifying also the rights of IDPs and refugees, including civil, political, economic and social rights that guarantee the wellbeing and subsistence of the population. These rights are increasingly consensual as evidenced in previous sessions.

\section{Libya}

The HR situation in Libya that had come under consideration at the UN was also taken into account on the initiative of Hungary on behalf of the EU at the HRC 15th special session (A/HRC/S-15/1: 6).

On the protection of civilians, UNHCHR and the CCSP have warned about the violent repression against peaceful protestors with mass killings; arbitrary arrests and detentions; torture of protestors; blockages to residential areas; impediment to medical and humanitarian assistance; use of foreign combatants (mercenaries) and violations of the fundamental rights and freedoms of the population.

On the initiative of the promoter of the session was presented draft resolution $\mathrm{A} / \mathrm{HRC} / \mathrm{S}$ 15/L.1, project that was adopted without a vote in Resolution S-15/I (A/HRC/S-I5/I: 1011). The draft resolution contained an explicit reference to offenses against civilians according to the information submitted by the Experts, including on fundamental rights and freedoms violations (A/HRC/S-15/L.1: 1-2). Although there was no reference to socio-economic rights unlike we have seen on Ivory Coast's Resolution, or to the use of mercenaries. Given the seriousness of the situation it was decided to establish a Commission of Inquiry to investigate IHRL violations in Libya in order to ensure accountability (A/HRC/S-15/L.1: 2). On Libya we find a consensual that could not be reached on Syria.

\section{Syria}

In the same vein of other UN bodies that analyzed the HR situation in Syria as soon as the conflict triggered, the HRC on the initiative of the USA analyzed this situation at its 16th special session (A/HRC/S-16/2: 5). This was the first of several extraordinary sessions on Syria in order to contribute to the resolution or management of the internal situation in the country, particularly important due to the blockade on the UN Security Council (Gowan and Pinheiro, 2014). This lack of consensus did not occur in the analysis of the Libyan conflict as we have seen.

The special session, as it will be evident in all the meetings convened, was not supported by Syria. Syria considered that its internal situation was an emergency situation/maintenance of public order, so it did not require the HRC's attention. This position was supported by Russia, China, Cuba, Venezuela, Ecuador, Pakistan and Nicaragua.

At the session, the Independent Experts did not take a stand on the classification of the conflict, which could undermine decision-making. They focused on the protection of civilians in terms of the HR and fundamental freedoms considered applicable to all 


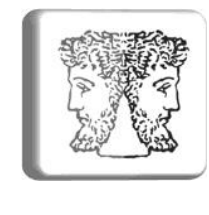

situations, including in emergency situations. Therefore, the UNHCHR among the offenses considered the use of live fire against peaceful protestors; the practices of detention and enforced disappearances; torture and ill-treatment; restrictions to freedoms of expression, assembly and association; persecution and intimidation; attacks against medical personnel, facilities and patients; attacks on densely populated areas; impediment of food delivery and assistance to the wounded and blockade of public services such as electricity and the transportation system, which could amount to crimes against humanity. The Special Rapporteur on the Right to Food on behalf of the HRC mandate holders also considered that reparations and compensations should be provided to victims and their families.

Taking the initiative in decision-making, the USA presented draft resolution A/HRC/S16/L. 1 approved in a non-consensual way in Resolution S-16/1. In the draft resolution it was reaffirmed the obligation of States to protect the fundamental rights and freedoms of civilians (A/HRC/S-16/L.1: 1) in line with the contribution of the Experts, indicating once again the importance of these Experts in considering the protection of civilians through the reporting of violations. However, socio-economic rights such as food and health care were not mentioned explicitly, alluding only to the right to social justice.

A second session on Syria which corresponded to HRC 17th special session was requested by Poland on behalf of the EU (A/HRC/S-17/1). This session had already interregional support, including from Arab countries, but maintained the same opposition block.

Similarly to the previous session, UNHCHR and the Special Rapporteur on Torture on behalf of the HRC mandate-holders did not take a position on the classification of the conflict. The protection of civilians was considered under HR and fundamental freedoms as provided by IHRL as reported at the 16th special session. These infractions were now also confirmed by the mission sent to Syria.

In order to boost decision-making, Poland the promoter of the session on behalf of the EU presented the draft resolution A/HRC/S-17/L.1 also approved in a non-consensual way in Resolution S-17/1. The project referred to the reports of the Experts, and to the report of the fact-finding mission on Syria which revealed the violations committed by the Syrian authorities that could amount to crimes against humanity. In this resolution States urged also the Syrian authorities to guarantee humanitarian and medical assistance (A/HRC/S-17/L.1: 1-3). It was also decided to send a commission of inquiry appointed by the HRC President to investigate alleged IHRL violations, including crimes against humanity, in order to identify those responsible (A/HRC/S-17/L.1: 3). This appointment denotes the strengthening of HRC competence in dealing with the infractions against civilians whose offenders should be held responsible. It was also decided to transmit the reports of this commission to the UNGA that should transmit them to relevant bodies. These decisions reinforced the warning about the seriousness of the violations committed against civilians and sleeked also a positioning by the main UN bodies.

Once again Poland on behalf of the EU requested a meeting on Syria in the light of the report submitted by the Commission of Inquiry. This report was discussed at the HRC 18th special session (A/HRC/S-18/2: 6). This session had greater interregional support than the previous ones but maintained the same opposition bock.

The Commission of Inquiry reported, as did the UNHCHR in the previous sessions, the $\mathrm{HR}$ and fundamental freedoms infractions against civilians in the country. Between these 
violations were the killings, including of children; torture and ill-treatment; rape and other forms of sexual violence; imprisonment or other forms of deprivation of liberty; enforced disappearances; blockages of residential areas with obstruction of access to water, food and other basic services; destruction of property and civil infrastructures; violations of children's rights (including the right to education); restrictions to the freedom of movement; use of hospitals as torture centers for injured demonstrators; impediments to the provision of medical care and restrictions on civil and political rights such as the freedom of expression and the rights to peaceful assembly or demonstration, infractions that required a strong decision-making from the HRC.

In this regard Poland the promoter of the session on behalf of the EU presented in the meeting the draft resolution A/HRC/S-18/L.1 approved in Resolution S-18/1, but as the previous ones in a non-consensual way (A/HRC/S-18/2: 8-9). This proposal referred to $\mathrm{HR}$ and fundamental freedoms violations according to the reports of the Experts, emphasizing once again the importance of delivering humanitarian assistance; to the voluntary return of refugees and IDPs and concern was also expressed about the lack of accountability (A/HRC/S-18/L.1: 1-3). In the amendment to the draft resolution it was added the reference to the importance of fulfilling the civil, political, economic, social and cultural rights of the population, which demonstrates a greater consensus on this issue. The UN bodies were also requested to take action based on the Resolution (A/HRC/S18/L.1/Rev.1: 2-4). This reference denotes the increasing pressure on the UN main bodies on the need to protect civilians.

A new session was requested by the representatives of Denmark, Kuwait, Qatar, Saudi Arabia, Turkey, the EU and the USA regarding the deterioration of the HR situation in Syria and the recent killings in El-Houleh, this would be the HRC 19th special session (A/HRC/S-19/1). This session had even more extensive support, highlighting the pressure on the need to solve the situation.

The Experts participating in the session, the UNHCHR and the Special Rapporteur on Extrajudicial, Summary or Arbitrary Executions on behalf of the HRC mandate holders referred, as in the previous sessions, to the protection of civilians in accordance with IHRL, which included the protection of HR and fundamental freedoms on the basis of the report of the Commission of Inquiry A/HRC/19/69.

Following these reports for the first time on the initiative of an Arab country, Qatar, was presented the draft resolution A/HRC/S-19/L.1 also approved in a non-consensual way in Resolution S-19/1 (A/HRC/S-19/2: 8). The proposal referred within the violations against civilians to the use of heavy artillery against residential areas and to physical abuses, specifying attacks on women and children, and violations of HR and fundamental freedoms (A/HRC/S-19/L.1:1-2), with no reference to economic and social rights unlike the previous ones. In the amendment to the draft resolution A/HRC/S-19/L.1/Rev.1 the UNHCHR statement was also recalled. In this statement the UNHCHR drew attention to the fact that the atrocities committed in Syria could amount to crimes against humanity, including its appeal to the UN Security Council to refer the situation to the International Criminal Court. This reference highlights the importance of the Independent Experts reports in decision-making given the prolonged severity of the situation which required the accountability of offenders. In the draft resolution it was also asked to the Commission of Inquiry to conduct an investigation on El-Houleh in order to identify those responsible (A/HRC/S-19/L.1:2), which reinforces the importance attached to accountability as a means of combating impunity. 
The HR situation in Syria was subsequently examined at the HRC 25th special session requested by the United Kingdom due to the attacks in Aleppo (A/HRC/S-25/I).

As participants in the session the UNHCHR, the CCSP and the Commission of Inquiry reported offenses against civilians in line with the previous session's reports. The protection of civilians was made under IHRL, which includes all HR and fundamental freedoms, but by 2016 there was already an explicit reference to IHL, which means that a consensus was reached on the qualification of the situation as an "armed conflict".

Following the initiative of the session, the United Kingdom presented the draft resolution A/HRC/S-25/L.1 approved once again in a non-consensual way in Resolution S-25/1 (A/HRC/S-25/2: 7-10). In this Resolution reference was made to IHRL and IHL violations committed by all parties to the conflict, including sexual and gender-based violence, also practiced against children. Reference was also made to the destruction of civilian infrastructures (schools and medical facilities) in Aleppo; attacks on civilians; removal of items from humanitarian convoys; deliberate interruptions of water supply; indiscriminate use of arms; use of starvation of civilians as a method of combat and the siege of populated areas (A/HRC/S-25/L.1: 1-3), without reference to economic and social rights, revealing some reluctance towards this category of rights. The Commission of Inquiry was also requested to conduct an inquiry into the events in Aleppo in order to make the offenders accountable (A/HRC/S-25/L.1: 3-4), being again the fight against impunity one of the main ways considered to dissuade the infractions.

\section{Central African Republic (CAR)}

On the initiative of Ethiopia on behalf of the $A G$ it was requested a session on the $H R$ situation in CAR, this was the HRC 20th special session (A/HRC/S-20/1). This session had a broad interregional support, including from the CAR. The country concerned was also aware of the risk of genocide due to the ethnic and religious dimension of the crisis in the CAR, which demonstrates the importance that States attach to cooperation through the work of international institutions.

The UNHCHR and the CCSP referred as offenses in the country to summary or extrajudicial executions based on religion; acts of sexual and gender-based violence; enforced disappearances; torture; mutilations; ill-treatment; imprisonment and arbitrary detention; looting and the destruction of property, in particular of religious buildings and the use of child-soldiers, infractions which led to a large number of refugees and IDPs.

Following these reports Ethiopia on behalf of the $A G$ presented the draft resolution A/HRC/S-20/L.1 consensually approved in Resolution S-20/1 (A/HRC/S-20/2). In this project Member States considered the HR and fundamental freedoms violations and abuses as mentioned by the Experts (A/HRC/S-20/L.1: 1-2), but once again without reference to economic and social rights, a topic that still reveals some reticence's.

\section{Iraq}

Iraq has requested a session (22nd special session) on the HR situation in the country in the light of the abuses committed by the so-called Islamic State, the Levant and associated groups (A/HRC/S-22/4). This session had broad interregional support, including from Russia and China contrary to what happened in the session about the HR 
situation in Sri Lanka, an important fact if we take into account that both situations deal with HR infractions in the fight against terrorism.

The UNHCHR has mentioned IHRL and IHL violations practiced by these groups against civilians (sexual violence; kidnappings; torture; persecution based on ethnicity, religion or sectarian affiliation; infractions to cultural and religious rights understood as identity rights; use of child-soldiers; destruction of infrastructures and livelihoods; impediment to humanitarian assistance; acts of harassment and intimidation and impediments to leave the places of combat safely). They also mentioned IHRL and IHL violations practiced by Iraqi forces and armed groups against these terrorist groups.

Assuming the initiative of the decision-making process, France supported by Iraq presented the draft resolution A/HRC/S-22/L.1, consensually approved in Resolution S22/I (A/HRC/S-22/4: 9). In this project were highlighted the HR and IHL violations committed by terrorist groups that could amount to war crimes and crimes against humanity as reported by the UNHCHR. It was also consensual the need to protect and provide assistance to civilians; protect civilian infrastructures; promote and protect all $\mathrm{HR}$ and fundamental freedoms; investigate the alleged abuses and promote the return of IDPs (A/HRC/S-22/L.1: 1-3). In this Resolution the protection of civilians agreed interconnected IHRL and IHL, including the obligation to guarantee the livelihoods of the population, but without reference to the violations committed by the government, a situation that had been criticized in the session on Sri Lanka.

\section{Boko Haram}

The activities of the terrorist group Boko Haram, which had consequences in Cameroon, Chad, Niger and Nigeria, were brought before the HRC by Algeria on behalf of the AG at its 23rd special session (A/HRC/S-23/1).

At the session the UNHCHR referred to the ethnic and sectarian offenses committed by Boko Haram (killings, abductions, sexual slavery, forced recruitment, looting and destruction of villages and towns) which led to a high number of IDPs and refugees who needed humanitarian and psychological assistance. There have also been reports of serious IHRL and IHL violations committed by Nigerian and other forces in reaction to this group's activities. In the same way the CCSP also recalled the need to respect HR and fundamental freedoms (judicial guarantees, freedom of thought, conscience and religion and the decision of each person to return to its own country).

Dealing once again with a situation in the African Continent Algeria on behalf of the AG presented the draft resolution A/HRC/S-23/L.1 consensually approved in Resolution S23/1 (A/HRC/S-23/2: 9). It was consensual the reference to IHRL and IHL atrocities and abuses committed by the terrorist organization against civilians in line with the reports of the Experts. HR and fundamental freedoms infractions were also mentioned, and concern was also expressed on the situation of IDPs and refugees (A/HRC/S-23/L.1: 3). But once again no mention was made to the violations committed by States in the fight against terrorism like in Iraq and Sri Lanka, and to the economic and social rights as guarantees of the population. 


\section{Burundi}

The seriousness of the HR situation prompted the USA to request a session on Burundi which would be the HRC 24th special session (A/HRC/S-24/I). This session had the support of Burundi also due to the awareness of the ethnic dimension of the conflict as happened with CAR.

At the session the UNHCHR, the Special Representative on the Prevention of Genocide and the CCSP, listed HR violations based on political and ethnic affiliation (extrajudicial executions; arbitrary arrests and detentions; enforced disappearances; beatings; looting, blockades of neighborhoods; torture; intimidation and the lack of livelihoods).

Following these reports the USA presented the draft resolution A/HRC/S-24/L.1 consensually approved in Resolution S-24/I (A/HRC/S-24/2: 9-10). In this session the promotion and protection of HR and fundamental freedoms was reaffirmed (A/HRC/S24/L.1: 1) as mentioned by the Experts, with States requesting also the UNHCHR to organize and dispatch to the country a mission composed of independent experts (A/HRC/S-24/L.1: 5). This decision emphasizes once again the significance of the fight against impunity in the HRC work.

\section{Conclusions}

From the cases analyzed, we highlight the initiative of the Western European and Other States Group in convening most of the sessions. This pro-activity is in line with the defense of a greater capacity of the HRC to deal with gross HR violations. There was also an assumption by the $A G$ of the issues in Africa that generate greater international consensus, unlike the situations in other regions as evidenced by the lack of consensus on Sri Lanka and Syria closer to the borders of great powers.

Notwithstanding the difficulties in framing current conflicts into the so-called classical categories (NIAC, international conflict, disturbances or internal tensions), there is an acceptance of the interrelation between IHL and IHRL in the protection of civilians as proposed by the Independent Experts. This complementarity, in addition to the minimum protection in NIAC conferred by common Article 3 to the GC, the only one agreed upon by all States, covers HR and fundamental freedoms with an emphasis on civil and political rights (freedom of opinion, expression, peaceful assembly, movement, religion or belief and the exercise of peaceful activities including political ones). The protection of civilian infrastructures and goods; the prohibition of all cruel, inhuman or degrading treatments or punishments, in which is included the sexual violence, abuse and assault; the prohibition of the use of child-soldiers; the obligation to provide the necessary livelihoods to the population even if through humanitarian assistance (food, water, health care, shelter), with emphasis on the part of the population considered most vulnerable refugees, IDPs, women and children are also guarantees agreed in the resolutions, in which all include the accountability of offenders.

\section{References}

A/HRC/S-4/1 (2006). Letter from Finland to the Human Rights Council (HRC).

A/HRC/S-4/5 (2006). Report of the HRC fourth special session (SS). 
A/HRC/S-5/1 (2007). Letter from Slovenia to the HRC

A/HRC/S-5/2 (2007). Report of the HRC fifth SS.

A/HRC/S-8/1 (2008). Letter from France to the HRC.

A/HRC/S-8/2 (2008). Report of the HRC eighth SS.

A/HRC/S-11/1 (2009). Letter from Germany to the HRC.

A/HRC/S-11/2 (2009). Report of the HRC eleventh SS.

A/HRC/S-14/1 (2010). Report of the HRC fourteenth SS.

A/HRC/S-15/1 (2010). Report of the HRC fifteenth SS.

A/HRC/S-16/2 (2011). Report of the HRC sixteenth SS.

A/HRC/S-17/2 (2011). Report of the HRC seventeenth SS.

A/HRC/S-18/2 (2011). Report of the HRC eighteenth SS.

A/HRC/S-19/1 (2012). Letter from Denmark, Kuwait, Qatar, Saudi Arabia, Turkey, the European Union and the United States of America to the HRC.

A/HRC/S-19/2 (2012). Report of the HRC nineteenth SS.

A/HRC/S-20/1 (2014). Letter from Ethiopia to the HRC.

A/HRC/S-20/2 (2014). Report of the HRC twentieth SS.

A/HRC/S-22/4 (2014). Report of the HRC twenty-second SS.

A/HRC/S-23/1 (2015). Letter from Algeria to the HRC.

A/HRC/S-23/2 (2015). Report of the HRC twenty-third SS.

A/HRC/S-24/1 (2015). Letter from the United States to the HRC.

A/HRC/S-24/2 (2015). Report of the HRC twenty-fourth SS.

A/HRC/S-25/1 (2016). Letter from the United Kingdom to the HRC.

A/HRC/S-25/2 (2016). Report of the HRC twenty-fifth SS.

A/HRC/S-26/1 (2016). Letter from Albania, Paraguay, United Kingdom and the United States to the HRC.

A/HRC/S-26/2 (2016). Report of the HRC twenty-sixth SS.

A/RES/60/251 (2006). HRC.

Cox, Eric (2010). "State Interests and the Creation and Functioning of the United Nations Human Rights Council" Journal of International Law and International Relations. 6(1), 87-120.

Gowan, Richard; Pinheiro, Paulo Sérgio (2014). "Syria" in Genser, Jared; Ugarte, Bruno Stagno (eds) The United Nations Security Council in the Age of Human Rights. Cambridge: Cambridge University Press, 434-453.

ICRC (2005). Customary IHL Database, disponível em https://ihldatabases.icrc.org/customary-ihl/eng/docs/home (consultado a 20 de julho de 2018). 
ICRC (2008). "Interview with Luis Alfonso De Alba" International Review of the Red Cross. 90(871), 489-499.

Lauren, Paul Gordon (2007). "Commission on Human Rights to the Human Rights Council" Human Rights Quarterly. 29, 307-345.

Ruggie, John (1998). Constructing the World Polity: Essays on international institutionalization. London/New York: Routledge.

Sheeran, Scott; Rodley, Nigel (eds.) (2013). Routledge Handbook of International Human Rights Law. New York: Routledge.

TIJ (2004). Legal Consequences of the Construction of a Wall in the Occupied Palestinian Territory Summary 2004/2.

Wendt, Alexander (1995). "Constructing International Politics" International Security. 20(1), 71-81. 